Original research article

\title{
Documentation of the treatment of pressure ulcers in home care agencies and welfare institutions in the Slovak Republic
}

\author{
Katarína Kačalová ${ }^{1,2}{ }^{*}$, Katarína Žiaková ${ }^{1}$ \\ ${ }^{1}$ Comenius University in Bratislava, Jessenius Faculty of Medicine in Martin, Department of Nursing, Martin, Slovak Republic \\ ${ }^{2}$ V̌̌eobecná zdravotná poistovňa, a. s., generálne riaditel'stvo, oddelenie metodiky zdravotných a revíznych činností, Bratislava, Slovak Republic
}

\begin{abstract}
Objective: To analyze the documentation of pressure ulcers at home care agencies (HCA) and welfare institutions (WI) to determine whether the records comply with legislative and contractual requirements.

Methods: Empirical data were collected from the documentation containing the Nursing Care Proposal (Proposal), the Course of disease, the Expert Findings, and the Records of examinations and prescription drugs for the treatment of pressure ulcer in the Health Insurance Information System (HIIS). Data collection was carried out from the year 2014 to 2018. Documentation of 101 patients treated for pressure ulcer which were reported to the General Health Insurence Company, a.p. (GHIC) for paymant, were included in the research file. Descriptive, frequency analysis methods were used to evaluate the results.

Results: Correct recording of localization, size, number and codes, less consistent writing of base, margins, secretion, and pressure ulcer surroundings. The analysis pointed to shortcomings in documenting continuous information on the pressure healing process and the diversity in the frequency of documenting the pressure ulcer healing process. $65.3 \%$ of the patients were treated by a specialist. The identity of the drugs reported in the HCA/WI documentation with the drugs reported in the HIIS was $46.5 \%$.

Conclusions: Problems in recording nursing care of pressure ulcers are mainly in the area of unstructured records of pressure ulcer healing process and in the uniformity of recorded information on applied drugs in nursing documentation and in HIIS.
\end{abstract}

Keywords: Content analysis; Documentation; Health insurance; Pressure ulcers

\section{Introduction}

Proper management of nursing documentation is a legislative and professional requirement of nursing practice and also a basis for the creation of contracts between health care providers and a health insurance company. According to the valid legislation in Slovakia, a proposal for the provision of nursing care (Journal of the Ministry of Health of the Slovak Republic, 2009), which is perceived as an indication form, is issued when receiving a patient in HCA or WI. The professional guidance of the Ministry of Health on the keeping of health documentation (Journal of the Ministry of Health of the Slovak Republic, 2009) replaced the previous professional guidance of the Ministry of Health of the Slovak Republic on the provision of home nursing care (Journal of the Ministry of Health of the Slovak Republic, 2000). The Journal of the Ministry of Health of the Slovak Republic (2000) defined the "Wound Treatment Protocol", which was, in addition to the Proposal, also included in the new Journal of the Ministry of Health of the Slovak Republic (2009). The nurses recorded the localization of the pressure ulcer in both written and graphical form, indicating its dimensions, degree of damage, causes of occurrence, doctor's office, course of treatment, frequency of bandages, and subsequently, in chronological order, the healing process. Giv- en that this form has not been replaced by another, nurses in practice either continue to use the original form or record the pressure ulcer assessment, but no longer in a structured form. Audits by the health insurance company found that the situation in practice caused inconsistency and, due to loss of legislation, inconsistency in documenting pressure ulcers. According to Cauble (2010), a systematic method for assessing pressure ulcers forms the basis for the choice of treatment method and prevention strategy, outcome management and third-party reimbursement. The comprehensive review of pressure ulcer should be at specific intervals taking into account the needs of the patient (2009), at least once a week (Melter, 2017; National pressure ulcer advisory panel, 2014; Registered Nurses' Association of Ontario, 2018), which is the foundation of individual care. Clear, accurate and timely records of nursing care improve patient safety, enhance the credibility of the documentation when it is being checked, promote communication, continuity, and decide on further treatment. The competence to indicate and prescribe medicines to treat pressure ulcers remains in the hands of a physician. This means that, in practice, the record of the indicated and applied medicine should be consistent in the Course of Disease, in the Proposal or in the Medical Discourse and in the HIIS. Similarly, in the Czech outpatient practice, a medical device voucher is issued by a doctor, while in the case of payment by a health insurance

\footnotetext{
* Author for correspondence: Katarína Kačalová, Všeobecná zdravotná poistovňa, a. s., generálne riaditel’stvo, oddelenie metodiky zdravotných a revíznych činností, Panónska cesta 2, 85104 Bratislava, Slovak Republic; e-mail: katarina.kacalova@vszp.sk http://doi.org/10.32725/kont.2019.042
}

Submitted: 2019-01-22 • Accepted: 2019-05-09 • Prepublished online: 2019-09-24 
company it also completes an application form approved by a review doctor (Mrázová et al., 2012). The Review Nurse in Slovakia monitors the compliance of pressure ulcers in the submitted accounting documents with reported care in the GHIC. Within the direct review of the health care provider, she checks the documentation of the pressure ulcers and then compares the records with the HIIS. In HIIS there are information about treatment of patients by nurse, physician at the specialized clinic and the data on drugs selected in the pharmacy or medical needs are recorded. This directly and indirectly reveals the cooperation of the doctor, nurse, and patient or family members and its reflection in the documentation. Sowerby (2018) reports that, even abroad, review nurses are monitoring the quality and cost-effectiveness of health services, while providing revisions to ensure that the necessary care is available without burdening the hospital with long-term stays.

Audit of records in nursing documentation means identifying, reviewing or verifying the implementation of certain specific aspects of nursing care (Nursing audit, 2010). Insufficient or absent recordings of pressure ulcer treatments, as well as discrepancies between the medications recorded in the decree, in the proposal or in the medical report and the drugs registered in the GHIC, indicate not only the reduced quality of the documentation but the suspicion of illegal activity. Shortcomings in documentation can create a number of obstacles for nursing and review nurses (LaBenne, 2016). Audit of records provides important information on pressure ulcer recording (Hansen and Fossum, 2016); well-documented documentation is a source of information and a tool for assessing the effectiveness or inefficiency of nursing activities (Somrová and Bártlová, 2012). Some foreign studies also point to a lack of nursing care records in line with a holistic approach, legislation and professional standards (Dehghan et al., 2015; Gunningberg et al., 2008; Høgsnes et al., 2016; Vainiomäki et al., 2008; Wang et al., 2007). In Slovakia, the use of a specific assessment tool is not required for the assessment of pressure ulcer assessment, but the correct entry of the necessary data, which should contain a brief description of the performance and evaluation, according to the applicable legislation in the Journal of the Ministry of Health of the Slovak Republic (2009; Act No. 576/2004). Nursing Standard - Nursing Care for a Patient with Pressure ulcer in the Home Environment (Framework Process Standards in Nursing Home Care, 2005) sets out the content of the Nursing Care Report within process and outcome criteria. In 2019, a standard procedure called Comprehensive Nursing Management of Patient with Decubitus came into force in Slovakia (Journal of the Ministry of Health of the Slovak Republic, 2019, p. 5), which describes the used classification NPUAP (National Pressure Ulcer Advisory Panel). At the same time, the above-mentioned legislative requirements and requirements of the standard concerning the documentation of pressure ulcers are also requirements of the health insurance company within the contractual relationship with HCA and WI. However, is the documentation regarding nursing care for pressure ulcers in the domestic environment in accordance with current legislation and standard?

The aim of the research part of the article was to analyze the contents of records of nursing care for pressure ulcer in HCA and WI to determine whether the records correspond to the legislative and contractual requirements of GHIC.

\section{Materials and methods}

The file selection was intentional. Contractual requirements for the maintenance of nursing documentation must comply with the legislation in all insurance companies. GHIC has the largest number of policyholders in Slovakia and at the same time the largest number of polymorbid, long-term patients, which was a prerequisite for selecting the relevant sample for the given research. Data collection was based on direct inspections from the year 2014 to 2018. 101 documentations of GHIC policyholders who had treated pressure ulcer were included in the research file.

\section{Ranking criteria:}

- a patient treated with HCA or WI who has a contract with GHIC;

- audit involving the audit of the nursing documentation;

- the presence of pressure ulcer treated for more than 1 month in the documentation;

- nursing care reported to the health insurance company for payment.

\section{Elimination criteria:}

- patients treated outside the specified time period;

- complete documentation not submitted for HCA or WI control;

- the presence of pressure ulcer treated less than 1 month in the documentation.

\section{Methods}

For the collection of empirical data, we used the method of content analysis of documentation in HCA and WI. In the context of resource triangulation (use of multiple data sources), we collected data from the nursing documentation containing the Proposal, the Course of disease, or the expert findings, and from the records contained in the HIIS. To ensure validity, a measuring tool was constructed using the two-stage analytical procedures to classify defined meaning units in the documentation.

\section{Phase - Qualitative analysis of recording units}

Recording units are analytical units of the content of texts that are incorporated into certain categories according to the form by which they are expressed (Švec et al., 1998, p. 151). We classified the recording units defined in the documentation of each patient within a single provider (HCA or WI). Foreign studies recommend the use of a scale to measure the quality of nursing documentation (Wang et al., 2007). The scale used in the qualitative analysis of the data recorded in the documentation was used by two analytical procedures:

A. Scale to determine the degree of acceptance of a meaning unit. The grades of scale 1 to 5 meant: 1 - fully agree, 2 strongly agree, 3 - partially agree, 4 - strongly disagree, 5 disagree. Given the correlation of two meaning units, in some cases, the degree of consent could not be assigned to one of the five grades of the rating scale. However, the assessment had to be made in view of its statistical significance, so we have chosen the numeric encoding character 6 - not evaluated for these cases.

B. Frequency Scale Evaluation of Continuous Assessment of Pressure ulcer. Due to the variety of interim evaluation records, this method of analysis was performed on a scale with the following coding: $\check{Z}$ (none), $\mathrm{P}$ (suspect), 1 (intermediate score recorded every 2 days), 2 (intermediate score recorded 1-2 times per week), 3 (interim evaluation recorded 2-3 times a month, 4 (interim evaluation recorded once a month), 5 (interim evaluation recorded less than once a month).

The qualitative analysis of the meaning units created the basis for the second phase of evaluation, with the individual meaning units forming a subcategory for the analytical category pressure ulcers. 


\section{Phase - Quantitative analysis of the encoded file}

In the second phase, we transformed the evaluation of meaning units from each analyzed documentation into a numerical- ly encoded file. At the same time, some parts are a representation of the process criterion (P) or result $(\mathrm{V})$ in accordance with nursing standards (Table 1 ).

\begin{tabular}{|c|c|c|c|}
\hline Category & Subcategory & Cod & Requirements for record \\
\hline \multirow{12}{*}{$\begin{array}{l}\text { Pressure } \\
\text { ulcers }\end{array}$} & Location of pressure ulcer & P1D & Physical location and laterality of pressure ulcer \\
\hline & Pressure ulcer size (length, width, depth) & P2D & $\begin{array}{l}\text { Record of dimensions (length, width, depth) in their maximum } \\
\text { range, in unit length unit }\end{array}$ \\
\hline & Pressure ulcer evaluation (base, margins, secretion) & P3D & $\begin{array}{c}\text { Brief description of the pressure ulcer base - its color, healing } \\
\text { phase, coating, character and amount of exudate, regularity and } \\
\text { appearance of pressure ulcer edges }\end{array}$ \\
\hline & $\begin{array}{c}\text { Description of pressure ulcer surroundings (skin coloration, } \\
\text { swelling, maceration) }\end{array}$ & P4D & $\begin{array}{c}\text { Description of skin condition around pressure ulcer - color } \\
\text { changes, symptoms of infection, hypertrophic manifestations, } \\
\text { humidity }\end{array}$ \\
\hline & $\begin{array}{c}\text { Record of pressure ulcer healing process (description } \\
\text { of pressure ulcer, description of surroundings, size, } \\
\text { localization) }\end{array}$ & V1D & $\begin{array}{l}\text { Summary of information regarding the process/stage of pressure } \\
\text { ulcer healing, determination of pressure ulcer degree or brief } \\
\text { description of base, secretion, pressure ulcer margins, location, } \\
\text { size and condition of the skin nearby }\end{array}$ \\
\hline & Frequency of enrollment evaluation in a controlled period & V2D & $\begin{array}{l}\text { Number of pressure ulcers assessment records during the } \\
\text { controlled period }\end{array}$ \\
\hline & $\begin{array}{c}\text { Specialized outpatient treatment (surgery, } \\
\text { dermatovenerology) }\end{array}$ & $5 \mathrm{D}$ & $\begin{array}{c}\text { Presence of reported pressure ulcer treatment by doctors in the } \\
\text { policyholder's account }\end{array}$ \\
\hline & $\begin{array}{l}\text { The identity of the drugs applied to the pressure ulcer listed } \\
\text { in the decree and in the HIIS }\end{array}$ & $6 \mathrm{D}$ & $\begin{array}{l}\text { The drugs listed in the Course of Disease are the same as those } \\
\text { that were selected in the pharmacy according to the policyholder's } \\
\text { account }\end{array}$ \\
\hline & $\begin{array}{l}\text { Identity of the indicated drugs in the Proposal or medical } \\
\text { finding with the doctor's office according to the HIIS }\end{array}$ & 7D & $\begin{array}{l}\text { Drugs listed in the Proposal/Professional Findings are the same } \\
\text { as those that were selected in the pharmacy according to the } \\
\text { policyholder's account }\end{array}$ \\
\hline & $\begin{array}{l}\text { Identity of the indicated drugs in the Draft or medical } \\
\text { finding with the drugs recorded in the Course of Disease }\end{array}$ & $8 \mathrm{D}$ & $\begin{array}{l}\text { Drugs listed in the Proposal/Professional Findings are consistent } \\
\text { with drugs reported in the Course of Disease }\end{array}$ \\
\hline & $\begin{array}{l}\text { The identity of the treatment of pressure ulcer treatment } \\
\text { with the relevant code reported by the insurance company }\end{array}$ & 9D & $\begin{array}{l}\text { The description of the pressure ulcer in the nursing } \\
\text { documentation is consistent with the treatment code reported by } \\
\text { the insurance company }\end{array}$ \\
\hline & $\begin{array}{l}\text { Identity of the number of pressure ulcers recorded with the } \\
\text { number of pressure ulcers reported to the health insurance } \\
\text { company }\end{array}$ & $10 \mathrm{D}$ & $\begin{array}{l}\text { The number of pressure ulcers recorded in the nursing } \\
\text { documentation is related to the number of pressure ulcers } \\
\text { reported by the insurance company }\end{array}$ \\
\hline
\end{tabular}

Legend: P1D-P4D, codes for nursing standard process criteria for subcategory pressure ulcer; V1D-V2D, codes for nursing standard result criteria for subcategory pressure ulcer; 5D-10D, codes for sub-category pressure ulcer.

The numerically coded file provided the basis for the quantitative analysis of the content of the documentation.

\section{Statistical methods}

Descriptive, frequency analysis with IBM SPSS 19 statistical software was implemented.

\section{Results and discussion}

The results point to the correct recording of localization (on the 1st and 2nd scale of assessment $=98 \%$ ) and the pressure ulcer size (1st and 2 nd $=78.2 \%$ ), but on the deficiencies in recording the base, margins, secretion (1st and $2 \mathrm{nd}=65.4 \%$ ) and pressure ulcer surroundings (1st and $2 \mathrm{nd}=39.6 \%$ ). The $48.5 \%$ documentation of the interim information on the pressure ulcer healing process was rated 3 or more (Table 2).

The frequency of evaluation of the pressure ulcer healing process was to be specified in more than 5 degrees of the evaluation scale from the point of view of objective evaluation, while the written evaluation was most often once a month (21.8\%) (Chart 1).

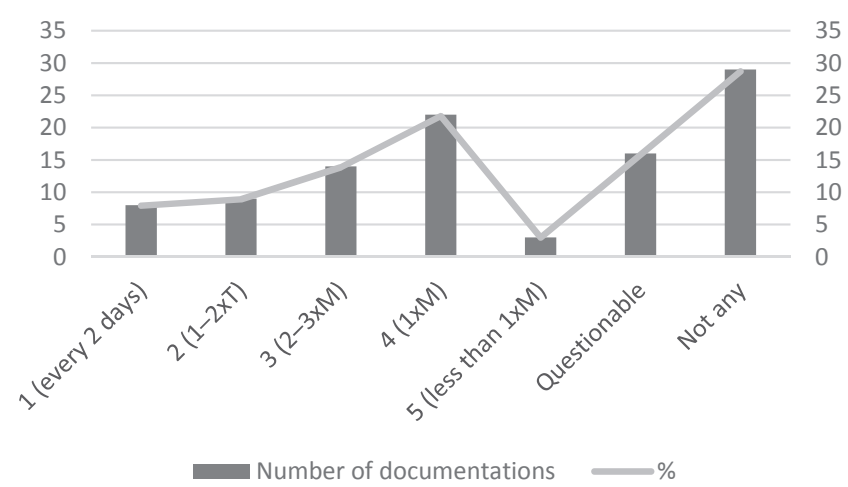

Chart 1. Frequency of evaluation of pressure ulcer healing process 
Table 2. Evaluation of process criteria and outcome of nursing care for pressure ulcer

\begin{tabular}{|c|c|c|c|c|c|c|c|c|c|c|}
\hline & \multicolumn{2}{|c|}{ P1D Localization } & \multicolumn{2}{|c|}{ P2D Size (l, w, d) } & \multicolumn{2}{|c|}{$\begin{array}{l}\text { P3D Evaluation (base, } \\
\text { margins, secretion) }\end{array}$} & \multicolumn{2}{|c|}{$\begin{array}{l}\text { P4D Surroundings } \\
\text { (skin coloration, } \\
\text { swelling, maceration) }\end{array}$} & \multicolumn{2}{|c|}{$\begin{array}{l}\text { V1D Ppressure ulcer healing } \\
\text { process (description of } \\
\text { pressure ulcer, description } \\
\text { of surroundings, size, } \\
\text { localization) }\end{array}$} \\
\hline & Number & $\%$ & Number & $\%$ & Number & $\%$ & Number & $\%$ & Number & $\%$ \\
\hline 1 & 96 & 95.0 & 36 & 35.6 & 45 & 44.6 & 30 & 29.7 & 20 & 19.8 \\
\hline 2 & 3 & 3.0 & 43 & 42.6 & 21 & 20.8 & 10 & 9.9 & 32 & 31.7 \\
\hline 3 & 2 & 2.0 & 12 & 11.9 & 12 & 11.9 & 11 & 10.9 & 10 & 9.9 \\
\hline 4 & 0 & 0.0 & 8 & 7.9 & 9 & 8.9 & 8 & 7.9 & 10 & 9.9 \\
\hline 5 & 0 & 0.0 & 2 & 2.0 & 14 & 13.9 & 42 & 41.6 & 29 & 28.7 \\
\hline in total & 101 & 100.0 & 101 & 100.0 & 101 & 100.0 & 101 & 100.0 & 101 & 100.0 \\
\hline
\end{tabular}

Legend: $1, \mathrm{w}, \mathrm{d}$ - length, width, depth; 1 to 5 , grades of scale: 1 - fully agree, 2 - strongly agree, 3 - partially agree, 4 - strongly disagree, 5 - disagree.

The identity of the drugs reported in the HCA/WI documentation with the drugs reported in HIIS was only $46.5 \%$ (on the scale of assessment 1 and 2), although $65.3 \%$ of the pa- tients were treated by a specialist. The identity of the number of procedures was $91.1 \%$ and the identity of the pressure ulcer treatment codes was $87.1 \%$ (Table 3 ).

Table 3. Comparison of recorded health care in documentation and in HIIS

\begin{tabular}{|c|c|c|c|c|c|c|c|c|c|c|c|c|}
\hline & \multicolumn{2}{|c|}{$\begin{array}{l}\text { 5D Specialized } \\
\text { outpatient } \\
\text { treatment }\end{array}$} & \multicolumn{2}{|c|}{$\begin{array}{l}\text { 6D course of disease } \\
\text { and HIIS (drug } \\
\text { identity) }\end{array}$} & \multicolumn{2}{|c|}{$\begin{array}{l}\text { 7D proposal/ } \\
\text { finding and HIIS } \\
\text { (drug identity) }\end{array}$} & \multicolumn{2}{|c|}{$\begin{array}{c}\text { 8D proposal/expert } \\
\text { finding and course } \\
\text { of disease (drug } \\
\text { identity) }\end{array}$} & \multicolumn{2}{|c|}{ 9D code identity } & \multicolumn{2}{|c|}{$\begin{array}{l}\text { 10D number } \\
\text { identity }\end{array}$} \\
\hline & Number & $\%$ & Number & $\%$ & Number & $\%$ & Number & $\%$ & Number & $\%$ & Number & $\%$ \\
\hline 1 & 66 & 65.3 & 40 & 39.6 & 43 & 42.6 & 49 & 48.5 & 88 & 87.1 & 92 & 91.1 \\
\hline 2 & 0 & 0 & 7 & 6.9 & 2 & 2.0 & 7 & 6.9 & 3 & 3.0 & 1 & 1.0 \\
\hline 3 & 6 & 5.9 & 10 & 9.9 & 9 & 8.9 & 5 & 5.0 & 3 & 3.0 & 4 & 4.0 \\
\hline 4 & 3 & 3.0 & 4 & 4.0 & 1 & 1.0 & 3 & 3.0 & 5 & 5.0 & 1 & 1.0 \\
\hline 5 & 26 & 25.7 & 15 & 14.9 & 15 & 14.9 & 8 & 7.9 & 2 & 2.0 & 3 & 3.0 \\
\hline 6 & 0 & 0.0 & 25 & 24.8 & 31 & 30.7 & 29 & 28.7 & 0 & 0.0 & 0 & 0.0 \\
\hline in total & 101 & 100.0 & 101 & 100.0 & 101 & 100.0 & 101 & 100.0 & 101 & 100.0 & 101 & 100.0 \\
\hline
\end{tabular}

Documentation of pressure ulcers in accordance with current legislation and standards reflects the quality of nursing care and is a decisive element in its payment. Pressure ulcers are a serious health and socio-economic problem that need to be solved causally and using evidence-based medical and nursing knowledge. Our research suggests that nurses do not have a significant problem in the recording of pressure ulcer localization (recorded in 95\%), which is also due to the relative clarity of its recording. Determination of pressure ulcer localization is important in terms of diagnosing the causes of the emergence of the ulcer, and in view of the healing prospects and setting the appropriate type of treatment. In Slovakia, if the pressure ulcer treatment is recorded in the Wound Treatment Protocol, the location of the pressure ulcer is determined by ticking the prescribed location on the body (eg, back, sacrum) and also in the "human body map". However, the wound care protocol or "human body map" is not determined by law, so when it comes to choosing a way of recording it is up to the nurse to decide. In the case that the said recording method is incomplete and there are important data missing (eg patient identification data, date of production), the quality of the nursing care documented will be reduced. The National pressure ulcer advisory panel (2014), as well as other guidelines such as Agency for
Healthcare Research and Quality (AHRQ) (2017) and the Association for the Advance of Wound Care (2010) recommend the use of the Bates-Jensen Assessment Tool (2001), in which the localization of the pressure ulcer is recorded from an anatomical point of view, with the determination of laterality and location, and the verbal determination of the location is supplemented by an entry in the "human body map" using the " $\mathrm{X}$ ".

The size of the pressure ulcer is crucial for selecting the appropriate size and shape of the cover. The complete record containing the length, width and depth of the pressure ulcer was found in $35.6 \%$ of the analyzed documentation. The length (along the patient's head line to the thumb axis) and the width (across the horizontal axis of the pressure ulcer) or grid in $\mathrm{cm}^{2}$ (using a transparent film) are recorded (Hlinková et al., 2015). Measurement of head-to-heel length in $\mathrm{cm}$ and left-to-right width with subsequent multiplication of data and obtaining a final size in $\mathrm{cm}^{2}$ is also recommended in the PUSH assessment tool (George-Saintilus et al., 2009). Morgan (2018) reminds us of the clock usage rule: the head is always at 12 o'clock, the feet at 6 o'clock, taking the longest length using the dial; when measuring width, the measure is perpendicular to length, above the widest aspect of the wound with a measurement of 3 to 9 hours. Swezey (2014) emphasizes the neces- 
sity of using the same measurement method because changes in dimensions determine whether healing is improving. The results show that in $42.6 \%$ of one parameter, the most common depth of pressure ulcer was missing. Gray et al. (2006) emphasize the greatest depth and edge conditionality identified by digital examination. Hlinková et al. (2015) recommend using a probe or a pean. According to the PSST (Bates-Jensen, 2001), the depth is measured by a five-stage scale, with $1=$ intact skin; 2 = partial loss of epidermis or dermis, superficial, shallow crater, possibly hyperplasia; 3 = total thickness loss of skin extending into subcutaneous tissues, not under fascia; 4 = necrosis without tissue layer visualization; 5 = damage to deep structures including tendons and articulated sheath. In a review article on wound healing, Chhabra et al. (2017) state, that more than 153 articles have been published in practice and that depth assessment has been found to be divided into two groups. The first is partial damage affecting the epidermal layer or it passes into the dermis. The second group expresses damage to the full thickness of the dermis with penetration through the skin into subcutaneous tissues, muscles, tendons or bones. These wounds heal with granulation and contraction, which requires more body energy and time. From this point of view, the necessity of measuring depth also results from the point of view of energy readiness of the organism for successful treatment.

In the analyzed documentation, $11.9 \%$ of cases found insufficient, half-recording of pressure ulcer size (for example, for two pressure ulcers, only 1 pressure ulcer was recorded; or for three ulcers, the width and length for two are reported and the third is recorded only for a size of "above $5 \mathrm{~cm}$ "). In $7.9 \%$, two factors were missing (eg, only "pressure ulcer $2 \mathrm{~cm}$ "). In $2 \%$ of the documentation, the pressure ulcer size was not mentioned at all. Unclear and incomplete information on pressure ulcers complicates further assessment and subsequent treatment decisions.

An evaluation of the degree of pressure ulcer or its healing phase with the description (base, margins, and secretion) pointed out that only $44.6 \%$ of the documentation contained a consistent degree of pressure ulcer or healing phase with description. At $20.8 \%$, the score was ranked 2 (on the rating scale), which meant that one of several factors was missing (e.g., scoring was found to be "mid-granulated" and edge ratings - "at the edge of necrosis", without secretion assessment). $11.9 \%$ of the documentation were scored at level 3 , often in the case of multiple pressure ulcers (e.g., from the 5 pressure ulcers, there were two common ulcers - notation: " $R$, $L$ foot $3 \times$ 3 , IV st, L and R trochanter IV st sacrum IV st."). In $8.9 \%$, only one factor was scored, or there were no or insufficient evaluations in the case of multiple pressure ulcers. In $13.9 \%$ of the documentation, there was no record of pressure ulcer degree or healing phase. The character of the tissue at the base of the pressure ulcer or other non-healing wound provides information on both the healing process and possible complications; therefore, this is important to record into the documentation. Gray et al. (2010) describe the Wound Healing Continuum (WHC) approach, which evaluates the color change base, Wound Infection Continuum, where microbial settlement and WEC (Wound Exudate Continuum) assessment are based on exudate volume and consistency. This approach is supported by other authors who describe the base by color (Stryja et al., 2011), describing the continuum of wound infection as a gradual increase in the number and virulence of microorganisms together with the response they elicit in the host (International Wound Infection Institute, 2016; al., 2015; Hlinková et al., 2015; Sood et al., 2014). There is also a need to address the strategy of cleaning, moisturizing and removing devitalized tissues (Krasner, 2004). Bulloch et al. (2004) assess the type of exudate (none, serosanguinolent, purulent) and the amount of exudate (no, increasing, a large amount), looking at whether exudate is not an accumulation of normal wound debris and dressing by-products. Another way to document the bottom of the pressure ulcer is to use the TIME model. Its aim is to relieve swelling, maintain optimal moisture removal of biofilm with reduction of bacterial load, and to support healing from wound edges (Pokorná and Mrázová, 2012). Veredas et al. (2015) conducted research on computerized wound detection based on color models, the resulting model was validated from 322 images manually segmented and labeled by experts, color histogram models were created for four different tissue types: granulation, yellow tissue wound on the base (slough), necrotic and tissue of wound margins. The final segmentation model was also computer-efficient in the case of poorly focused images and wounds with a non-specific nature. Dowset and Newton (2005) emphasize the need to document margins that play an important role in the epithelialization phase, where the epidermal cells divide, migrate and mature from the margins.

Documentation of the pressure ulcer surrounding (skin discoloration, swelling, and maceration) was consistent in $29.7 \%$ of the analyzed documentation and in $9.9 \%$ of the description there were deficiencies (grade 2 on the rating scale). In $10.9 \%$ of the documentation, only a partial description of the surroundings was present (for example, in the case of two pressure ulcers the description of the surroundings was only one) and in $41.6 \%$, the description of the surroundings was not present at all. The condition of the pressure ulcer also indicates the potential for treatment. Maceration, inflammation, conditional and tunneling, edema and pain are signs of a potentially non-healing wound (Fraser, 2017). Kopal (2014) points out that $60 \%$ of patients have a contact allergy to some substances often used in the treatment of pressure ulcers, so it is necessary to document the allergy.

Within the criterion of the result of the continuous evaluation of the pressure ulcer healing process, only $19.8 \%$ of the documentation was rated 1 and $31.7 \%$ was rated 2 , which means that the description of one factor was missing in the documentation (e.g., surrounding description). $9.9 \%$ of the documentation were scored at level 3 and at the same percentage at grade 4 . In this documentation, there were two factors missing or only one of the two pressure ulcers was recorded (grade 3 ). In other documentation (grade 4) there was a lack of multiple factor recording (e.g., "multiple pressure ulcers on left shin"). In $28.7 \%$, the continuous evaluation of the pressure ulcer healing process was not recorded. In the course of enrollment of the mid-term assessment, expertise, experience, clear enrollment styling and, in particular, a certain amount of time is required, which in practice represents a problem for nurses.

The evaluation frequency (V2D) was varied. In some documentation, pressure ulcer assessment were recorded every 2 days (7.9\%), others were 1 to 2 times a week (8.9\%), with the most frequent evaluation being 1 monthly (21.8\%), slightly less 2 to 3 times a month (13.9\%), less than 1 time per month in $3 \%$, and no record of interim evaluation in $28.7 \%$. In $15.8 \%$ of the documentation, the interim evaluation record was repeatedly (duplicated) for longer than 1 month, so the term "Suspicious" was used for this type, which means that it was clear from the record itself that the assessment could not be considered plausible. The above results show that the issue of pressure ulcer healing process needs to be given greater attention in the training of nurses preparing for the professional activity in HCA and the WI as well as in the activity of the re- 
view nurse. Morton and Phillips (2016) point out that in many cases poor healing is associated with inadequate care, so care procedures for the healing wound and its treatment should be consistently recorded. According to Hlinková et al. (2015), assessment of pressure ulcers should be recorded at first treatment and then at each following treatment. According to the National pressure ulcer advisory panel guidelines (2014), it is recommended that the pressure ulcer is assessed at least once a week, to enable timely detection of complications and to adjust the treatment plan. In accordance with the legislation in force in Slovakia, HCA and WI nurses should record an evaluation of the treatment of pressure ulcer treatment after each treatment, record a more detailed description of it and, in case of deterioration of the pressure ulcer condition, consult with the attending physician. One of the English hospitals has introduced an innovative computerized system for recording and reporting the risks and the occurrence of pressure ulcers to ensure their timely assessment and proper treatment (Plaskit et al., 2015). In Sweden, Gunningberg et al. (2008) compared accuracy in recording the prevalence and prevention of pressure ulcers before and after the introduction of an electronic health record with pressure ulcer evaluation templates. They found that the accuracy of pressure ulcer recording improved in electronic record compared to paper, but there were shortcomings in the electronic record, which meant that the records did not serve as a valid source of information on the prevalence and prevention of pressure ulcers. Electronic recording of nursing care in the documentation can also lead to the risk of using it in the wrong way with subsequent creation of erroneous entries (copying of texts with original dates or with older or outdated information, or copying of text between individual records in different patients). Clearly defined standards for electronic records are essential to ensure patient safety.

Shortcomings in the documentation of nursing care, inconsistencies in the use of classification systems, or routine selection of diagnoses are confirmed by several home and foreign studies (Hansen and Fossum, 2016; Chamanga and Ward, 2015; Jarošová et al., 2012, Hlinková et al. 2015; Žiaková and Gurková, 2010). Hansen and Fossum (2016) carried out a retrospective audit of 155 patient records, finding that $26 \%$ of patients were reported in the documentation, of whom $45 \%$ were not classified. Nurses do not commonly use pressure ulcer risk assessment tools and often rely on their own knowledge and experience to evaluate them (Samurivo and Dowding, 2014). Therefore, in the interest of the patient, attention should also be paid to the issue of pressure ultraviolet monitoring in the context of control activities (Law 581/2004).

The assessment of the compliance criterion with the health insurance information system pointed to irregularities. $65.3 \%$ of the patients were treated by a specialist (surgeon, dermatovenerologist), but only $39.6 \%$ of the cases found full agreement on the medications recorded in the course of disease and in the HIIS. $6.9 \%$ of the drugs contained more drugs in comparison with the reported data in the HIIS, in $9.9 \%$ the drug administration was recorded alternately, once in accordance with the HIIS and in other cases in the mismatch, or more drugs were issued and in another time period continuity as recorded in the course of disease. In $4 \%$ in the course of disease, drug records indicated in the previous period persisted despite the change according to HIIS, or more drugs were issued according to HIIS but only one application was recorded in the course of disease. The indication of local medicines for treating pressure ulcers is within the competence of the physician, but the problem arising from patient immobility often inhibits direct examination by a physician. Drug indication in such cases is often carried out on the basis of information provided by the nurse or relatives, and any communication failure or drug substitution in the pharmacy results in contradictory findings in the control. Other discrepancies were found in the comparison of the recorded medications applied to the pressure ulcer in the proposal or in the medical report and in the HIIS.

The proposal is a legal document where nurses, in collaboration with a physician, record the intended application of drugs used to treat a pressure ulcer. The given form is signed by the attending physician and HCA or WI professional nurse. Full agreement was found only in $42.6 \%$ of the documentation, while in $14.9 \%$ there was a complete discrepancy in the records. In $30.7 \%$, there was no information on prescribed drugs in the HIIS, so it was not possible to compare the conformity with the proposal or the professional finding (rated at level 6).

The results showed $48.5 \%$ consensus when analyzing the matched drug recordings in the course of disease and in the proposal or Expert Findings. In the documentation, in $6.9 \%$ there was, according to the proposal, one drug less than it was recorded in the course of disease. In $5 \%$ (grade 3 ), fewer drugs were recorded in the course of disease than in the proposal, or the drug proposal was once matched, sometimes not. In $28.7 \%$ of the cases, there were no drugs listed in the proposal or expert findings, which means that it was not possible to assess compliance with the record in the course of disease.

The identity of the pressure ulcer treatment performance code recorded in the course of disease and reported to the health insurance company was at the level of $87.1 \%$, and the consistency of the number of pressure ulcers recorded in the course of disease and reported to the health insurance company was fully consistent in $91.1 \%$ of the analyzed documentation.

\section{Conclusions}

The research results point to deficiencies in documenting the treatment of pressure ulcers, especially in the area of unstructured records of the pressure ulcer healing process, as well as to issues related to the consistency of recorded information on applied drugs in the nursing documentation and in the insurance information system. Thorough recording of individual findings in the treatment of pressure ulcers is part of a comprehensive approach, facilitating early detection of the problem, creating space for mutual communication between healthcare professionals and effective treatment settings.

\section{Ethical aspects and limitations of the research}

Ethical aspects of resource citation have been observed and all personal data of healthcare providers and patients were processed anonymously. The authors consider the limitation of the study to be the selection of data obtained from inspections by only one of the three health insurance companies currently operating in Slovakia.

\section{Conflict of interests}

The authors have no conflict of interests to declare. 


\section{Dokumentovanie ošetrovania dekubitov v ADOS a ZSS v podmienkach Slovenskej republiky}

\section{Súhrn}

Ciel': Obsahovou analýzou dokumentovania dekubitov v agentúrach domácej ošetrovatel'skej starostlivosti (ADOS) a zariadeniach sociálnych služieb (ZSS) zistit', či záznamy zodpovedajú legislatívnym a zmluvným požiadavkám.

Metódy: Empirické údaje boli zbierané z dokumentácie obsahujúcej Návrh na poskytovanie ošetrovatel'skej starostlivosti (Návrh), dekurz, odborné nálezy a zo záznamov o vyšetrení a preskripcii liečiv na ošetrenie dekubitov v informačnom systéme zdravotnej poistovne (ZPIS). Zber údajov bol realizovaný od r. 2014 do r. 2018. Do výskumného súboru bolo zaradených 101 dokumentácií pacientov, ktorí mali ošetrovaný dekubit a starostlivost' bola vykázaná Všeobecnej zdravotnej poistovni, a. s., (VšZP) k úhrade. Pre vyhodnotenie výsledkov boli použité metódy deskriptívnej, frekvenčnej analýzy.

Výsledky: Správne zaznamenávanie lokalizácie, vel'kosti, počtu a kódov, menej dôsledný zápis spodiny, okrajov, sekrécie a okolia dekubitov. Analýza poukázala na nedostatky v dokumentovaní priebežných informácií o procese hojenia dekubitu a rôznorodost' vo frekvencii dokumentovania procesu hojenia dekubitu. 65,3 \% pacientov bolo ošetrených odborným lekárom. Zhodnost' liečiv zaznamenaných v dokumentácii ADOS/ZSS s liečivami zaznamenanými v ZPIS dosahovala 46,5%.

Záver: Problémy pri zaznamenávaní ošetrovatel'skej starostlivosti o dekubity sú predovšetkým v oblasti neštruktúrovaných zápisov procesu hojenia dekubitov a v jednotnosti zaznamenaných informácií o aplikovaných liečivách v ošetrovatel'skej dokumentácii a v ZPIS.

Kl'účové slová: dekubity; dokumentácia; obsahová analýza; zdravotná poist'ovňa

\section{References}

1. Act No 576/2004 [Zákon č. 576/2004 Z. z., o zdravotnej starostlivosti, službách súvisiacich s poskytovaním zdravotnej starostlivosti a o zmene a doplnení niektorých zákonov]. In: Zbierka zákonov Slovenskej republiky, čiastka 243/2004 (Czech).

2. Act No 581/2004 [Zákon č. 581/2004 Z. z., o zdravotných poistovniach, dohl'ade nad zdravotnou starostlivostou a o zmene a doplnení niektorých zákonov]. In: Zbierka zákonov Slovenskej republiky, čiastka 246/2004 (Czech).

3. Association for the Advancement of Wound Care (AAWC) (2010). Guideline of Pressure Ulcer Guidelines. Malvern, Pennsylvania: Association for the Advancement of Wound Care (AAWC). [online] [cit. 2018-10-13]. Available from: https://s3.amazonaws.com/aawc-new/memberclicks/ AAWCPressureUlcerGuidelineofGuidelinesAug11.pdf

4. Bates-Jensen B (2001). Bates-Jensen wound assessment tool. [online] [cit. 2018-02-19]. Available from: http://wwwoundcare. $\mathrm{ca} /$ Uploads/ContentDocuments/BWAT.pdf

5. Bulloch G, Berwiczonek H, Butler S, Sinclair L, Lymer V, de Groot G, et al. (2004). Skin and wound care manual. Calhary Health Region: Skin Integrity Team.

6. Cauble D (2010). A critical appraisal of two measures for pressure ulcer assessment. SOJNR 10(4). [online] [cit. 2018-02 12]. Available from: https://www.snrs.org/sites/default/files/ SOJNR/2010/Vol10Num04Art06.pdf

7. Chamanga E, Ward R (2015). Documentation and recordkeeping in pressure ulcer management. Nursing Standard 29(36): 56-63. DOI: 10.7748/ns.29.36.56.e9674.

8. Chhabra S, Chhabra N, Kaur A, Gupta N (2017). Wound healing concepts in clinical practice of OMFS. J Maxillofac Oral Surg 16(4): 403-423. DOI: 10.1007/s12663-016-0880-z.

9. Dehghan D, Dehghan M, Sheikhrabori A (2015). The Quality of Clinical Documentation of Patients Admitted to an Iranian Teaching Hospital: A two-year Impact of Clinical Governance. In Asian Journal of Nursing Education and Research; Raipur. 5(2): 159-166. DOI: 10.5958/2349-2996.2015.00033.6

10. Dowsett $C$, Newton H (2005). Wound bed preparation: TIME in practice. Wounds UK 1(3): 58-70.

11. Framework Process Standards in Nursing Home Care (2005). [Rámcové procesuálne štandardy v domácej ošetrovatel'skej starostlivosti]. Mimoriadna príloha zdravotníckych novín a časopisu Sestra 2005(3): 1-38 (Czech).

12. Fraser $B$ (2017). The colour of wounds and its implication for healing. Health Times. [online] [cit. 2018-02-22]. Available from: https://healthtimes.com.au/hub/wound-care/59/ practice/bf1/the-colour-of-wounds-and-its-implication-forhealing/45/

13. George-Saintilus E, Tommasulo B, Cal CE, Hussain R, Mathew N, Dlugacz Y, et al. (2009). Pressure ulcer PUSH score and traditional nursing assessment in nursing home residents: do they correlate? J Am Med Dir Assoc 10(2): 1414-144. DOI: 10.1016/j.jamda.2008.10.014

14. Gray D, White R, Cooper P et. al. (2010). Applied Wound Management and using the Wound Healing Continuum in Practice. Wound Essentials 5: 131-139.

15. Grey JE, Enoch S, Harding KG (2006). Wound assessment. BMJ 332(7536): 285-288. DOI: 10.1136/bmj.332.7536.285

16. Gunningberg M, Dahm MF, Ehrenberg A (2008). Accuracy in the recording of pressure ulcers and prevention after implementing an electronic health record in hospital care. Qual Saf Health Care 17(4): 281-285. DOI: 10.1136/qshc.2007.023341.

17. Hansen RL, Fossum M (2016). Nursing documentation of pressure ulcers in nursing homes: comparison of record content and patient examinations. Nurs Open 3(3): 159-167. DOI: $10.1002 /$ nop2.47.

18. Hlinková E, Nemcová J, Miertová M, et al. (2015). Nehojace sa rany. Martin: Osveta.

19. Høgsnes L, Danielson E, Norbergh KG, Melin-Johansson C (2016). Healthcare professionals' documentation in nursing homes when caring for patients with dementia in end of life a retrospective records review. J Clin Nurs 25(11-12): 16631673.

20. International Wound Infection Institute (2016).Wound infection in clinical practice. [online] [cit. 2018-02-11]. Available from: https://www.bbraun.com/content/dam/catalog/ bbraun/bbraunProductCatalog/S/AEM2015/en-01/b3/woundinfection-inclinicalpractice.pdf.bb-.19719474/wound-infectioninclinicalpractice.pdf

21. Jarošová D, Sikorová L, Marečková J, Pajorová H (2012). Elektronická dokumentace pro ošetřovatelskou diagnostiku v domácí péči. Praktický lékař 92(2): 105-107.

22. Journal of the Ministry of Health of the Slovak Republic (2000). [Vestník Ministerstva zdravotníctva Slovenskej republiky]. Odborné usmernenie MZ SR č. SZS-1373/2000 pre poskytovanie zdravotnej starostlivosti v Agentúrach domácej ošetrovatel'skej starostlivost. 48(35-56) (Czech).

23. Journal of the Ministry of Health of the Slovak Republic (2009). [Vestník Ministerstva zdravotníctva Slovenskej republiky]. Odborné usmernenie MZ SR č. 07594/2009-OZS o vedení zdravotnej dokumentácie. 5(42-48): 309-360 (Czech).

24. Kopal T (2014). Starostlivost́ o okolie rany. In: Marková B (Ed.). 68. chirurgický deň Kostlivého. Banská Bystrica: Marko BB.

25. Krasner DL (2004). Control of exudate and periwound skin care. In: Téot L, Banwell PE, Ziegler UE (Eds). Surgery in Wounds. 
Berlin: Springer, pp. 101-108. DOI: 10.1007/978-3-642-593079_11.

26. LaBenne $J$ (2016). Is utilization review the career for you? A utilization review nurse helps ensure authorization of services, which minimizes costs and maximizes reimbursement. Am Nurse Today 11(5).

27. Melter C (2017). Pressure ulcer prevention and treatment assessment, wound care, and healing. Wild Iris Medical Education. [online] [cit. 2018-10-28]. Available from: https:// wildirismedicaleducation.com/courses/pressure-ulcerassessment-treatment-ceu

28. Morgan N (2018). Measuring wounds. Wound Care Advisor. [online] [cit. 2018-02-22]. Available from: http:// woundcareadvisor.com/measuring-wounds/

29. Morton LM, Phillips TJ (2016). Wound healing and treating wounds: Differential diagnosis and evaluation of chronic wounds. J Am Acad Dermatol 74(4): 589-605. DOI: 10.1016/j. jaad.2015.08.068.

30. Mrázová R, Pokorná A, Krejcar M (2012). Možnosti v hojení ran. Med praxi 9(2): 83-86.

31. National pressure ulcer advisory panel, European pressure ulcer advisory panel and Pan Pacific Pressure Injury Alliance (2014). Prevention and treatment of pressure ulcers: quick reference guide. Haesler E (Ed.). Perth: Cambridge Media.

32. Nursing audit (2010). Nursing Management. [online] [cit. 20182-02]. Available from: http://currentnursing.com/nursing management/nursing_audit.html

33. On-time pressure ulcer assessment (2017). Agency for Healthcare Research and Quality (AHRQ). [online] [cit. 201810-13]. Available from: http://www.ahrq.gov/professionals/ systems/long-term-care/resources/ontime/pruhealing/ pruhealing-assessment.html

34. Plaskit A, Heywood N, Arrowsmith M (2015). Recording pressure ulcer risk assessment and incidence. Nurs Stand 29(46): 54-61. DOI: 10.7748/ns.29.46.54.e10013.

35. Pokorná A, Mrázová R (2012). Kompendium hojení ran pro sestry. Praha: Grada.

36. Registered Nurses' Association of Ontario (RNAO) (2018). Educational Workshop for RNs and RPNs: Assessment and Management of Pressure Ulcers [online] [cit. 2018-09-13]. Available from: https://rnao.ca/sites/rnao-ca/files/Assessment and_Management_of_Pressure_Ulcers_-_Part_A.pdf
37. Samuriwo R, Dowding D (2014). Nurses' pressure ulcer related judgements and decisions in clinical practice: a systematic review. Int J Nurs Stud 51(12): 1667-1685. DOI: 10.1016/j. ijnurstu.2014.04.009.

38. Save Oklahoma's Skin (2009). A systems approach to quality improvement in health care: toolkit for pressure ulcer prevention and treatment. [online] [cit. 2018-08-13]. Available from: https://www.ofmq.com/sites/default/files/FULL\%20 SOS\%20TOOLKIT.pdf

39. Somrová J, Bártlová S (2012). Importance of accreditation of hospitals for nursing. Kontakt 14(4): 410-420.

40. Sood A, Granick MS, Tomaselli NL (2014). Wound dressings and comparative effectiveness data. Adv Wound Care (New Rochelle) 3(8): 511-529. DOI: 10.1089/wound.2012.0401.

41. Sowerby $\mathrm{H}$ (2018). What does a utilization review nurse do? [online] [cit. 2018-02-12]. Available from: http://www. innerbody.com/careers-in-health/how-to-become-a-utilizationreview-nurse.html

42. Stryja J, et al. (2011). Repetitorium hojení ran 2. Semily: GEUM.

43. Swezey L (2014). Wound assessment - wound location and size. [online] [cit. 2018-02-11]. Available from: https:// woundeducators.com/wound-size/

44. Švec Š, et al. (1998). Metodológia vied o výchove. Kvantitatívnoscientické a kvalitatívno-humanitné prístupy. Bratislava: IRIS.

45. Vainiomäki S, Kuusela M, Vainiomäki P, Rautava P (2008). The quality of electronic patient records in Finnish primary healthcare needs to be improved. Scand J Prim Health Care 26(2): 117-122. DOI: 10.1080/02813430701868806.

46. Veredas F, Mesa H, Morente L (2015). Efficient detection of wound-bed and peripheral skin with statistical colour models. Med Biol Eng Comput 53(4): 345-359.

47. Wang N, Yu P, Hailey D, Oxlade D (2011). Developing measurements of quality of electronic versus paper-based nursing documentation in Australian aged care homes. eJHI 6(1): e7.

48. Žiaková K, Gurková E (2010). Využitie princípov praxe založenej na dôkazoch pre zlepšenie ošetrovatel'skej diagnostiky v klinickej praxi. Ošetřovatelství a porodní asistence 1(1): 17-23. 